\title{
The influence of private primary schooling on children's learning: evidence from three generations of children living in the UK
}

Samantha Parsons*, Francis Green, George B. Ploubidis, Alice Sullivan and RD Wiggins.

\begin{abstract}
Much has been made of the academic success of children who have attended private secondary schools in Britain, but far less attention has been directed to whether there are similar benefits from attending a private primary school. Using data from three British birth cohorts - born in 1958, 1970 and 2000/1 this paper profiles the family background and personal characteristics of children at state funded and private fee-paying schools, and then investigates the effect of the type of primary school attended on academic progress made during the primary school years. Applying 'value added' linear regression and propensity score matching techniques, we find evidence of a positive association between private primary school attendance and a child's cognitive progress in all three cohorts. This effect remains after accounting for a wide range of individual and family characteristics, despite the very different times and socio-economic circumstances experienced by the children and their families in the three studies. Findings are discussed and compared against contrasting international findings.
\end{abstract}


Key words: private primary school, academic achievement, cohort, longitudinal, UK

\section{Acknowledgement}

This work was funded as part of an Economic and Social Research Council award entitled 'Schooling and unequal outcomes in youth and adulthood'. Our thanks to the NCDS, BCS70 and MCS cohort members, whose continued participation in the cohort studies is greatly appreciated.

${ }^{*}$ Corresponding author: Dr Sam Parsons, Centre for Longitudinal Studies, UCLInstitute of Education, London WC1 OHB

Email: sam.parsons@ucl.ac.uk

Word count: 6727 (abstract and main body of text, excluding tables and references) 


\section{Introduction}

Much media attention and public scrutiny in Britain is placed on the success of privately education children in public examinations at age 16 and 18 (Dearden et al, 2002; Sullivan and Heath, 2003; Feinstein and Symons, 1999) ${ }^{1}$. This scrutiny is also focused on students' acceptance on to degree courses at high status universities (The Sutton Trust, 2008, 2016; Sullivan et al, 2014; Ogg et al, 2009) and into high earning, high status, influential occupations later on (Green et al, 2017; Macmillan et al, 2015; Green et al, 2015; Sullivan et al, 2016). However, less attention has been focused on private primary schools. One exception is Green et al. (2012) which shows a link between private primary schooling and higher earnings some twenty years later. The unique contribution of the current paper is to consider whether attending a private primary school made a difference to learning during the primary school years for three cohorts of children who started primary school in the UK in the 1960s, 1970s and 2000s.

Latest figures from 2015 show that the UK independent sector as a whole educates around 625,000 children in around 2,600 schools. This equates to $6.5 \%$ of the total number of school children in the UK (and over 7\% in England) with the figure rising to more than $18 \%$ of pupils over the age of 16 . This proportion has remained remarkably stable over time (Independent Schools Council, www.isc.co.uk), but is the highest number of children to be educated in the private sector since records began in 1974 due to population increases.

\footnotetext{
${ }^{1}$ In 2015, among privately educated children the top grades of $A$ and $A^{*}$ were awarded to $60 \%$ of all entries at GCSE and half of all A Level entries. This compares with overall figures of $26 \%$ and $22 \%$ respectively (www.isc.co.uk).
} 
Preparatory or 'prep' schools are equivalent to the primary and middle schools of the state education sector in the UK, and far less is known about the children being educated at private primary or preparatory schools and what, if any, early advantages are experienced. In England, Wales and Northern Ireland, primary schools educate children from age four to 11, whereas in Scotland children do not move on to secondary school until they are age 12 .

Historically, preparatory schools were for boys between the ages of 8 (Year 4) up to 13 years (Year 8), who were being prepared for the Common Entrance Examination, the key to entry into many secondary independent schools, with the most prestigious secondary schools listing the preparatory schools which have success in having a significant number of children entered and accepted. However, from the mid-late nineteenth century there has been an equivalent parallel system for educating girls, when forward-thinking feminists funded schools such as Cheltenham Ladies College (1853) and Roedean (1885). (For further details see Delamont, 1989.) Today, there are any preparatory schools now educate girls and an increasing number are co-educational with pre-prep and nursery sections that are dedicated to the education of the very youngest children. However, preparatory schools remain very much in the minority. For example, whilst there were over 1,500 preparatory schools across the UK in 2016 (Wilkins, 2016), in England alone there were 16,766 state-funded primary schools educating more than 4.5 million children in 2015. This compares to around 305,000 pupils attending private primary schools ${ }^{2}$, which equates to

\footnotetext{
${ }^{2}$ Numbers here restricted to children between age 2-11 years attending a private school, to be comparable with state funded primary schools which educate children from nursery (age two and under) up to Year 6 (age 11). Preparatory schools traditionally educate children up to age 13.
} 
6.3\% of all school primary school aged children in England (DfE, 2015).

In this paper we examine private 'prep' school attendance across three generations of children living in the UK. Private and prep schooling has changed greatly over the decades. The grim physical conditions and brutal corporal punishment described by Orwell in 'Such, Such were the Joys' for example, would certainly not be tolerated by modern parents. Similarly, the uncovering of physical and sexual abuse in boarding schools has led to change ${ }^{3}$. Far fewer children now board, fewer schools are single sex and although standards of comfort for pupils have much improved, fees are far higher. For example, in 1980, the average cost of sending a child to a preparatory school as a day student amounted to $19.9 \%$ of average household equivalised income. In 2015 this had increased to $49.6 \%$ of average household equivalised income ${ }^{4}$. By 2015 , just $4.7 \%$ of all pupils in a preparatory school were boarders with this figure having declined steadily over the years, from $14.8 \%$ in $1990,9.5 \%$ in 2000 and $7.1 \%$ in 2010. Another significant difference between state-funded and private primary schools in the UK, is that private schools are not obligued to follow the National Curricullum as set out by the country's government (the curricullum is different in Scotland from the other UK countries). The range of subjects offered to children from a younger age is also broader, with both classical and modern languages often being taught from age seven. These are traditionally not

\footnotetext{
${ }^{3}$ https://www.theguardian.com/society/2014/may/04/abuse-britain-private-schools-personal$\underline{\text { memoir }}$

${ }^{4}$ Calculations are authors own. Data on fees taken from Independent School Council Annual Census reports 1984-2015; average Independent Association of Preparatory School fees 19802005; Junior School fees 2010-2015. Household income date from Institute of Fiscal Studies report 'Living Standards, Poverty and Inequality in the UK: 2015' http://www.ifs.org.uk/tools_and_resources/incomes_in_uk
} 
introduced in the state sector until children reach secondary school.

\section{Primary schooling and early academic or cognitive progress}

Existing literature on the role of private primary schools on cognitive achievement has largely focused on faith schools, with much of this based on US Catholic schools (e.g. Lee and Stewart, 1989; Jones, 1998; Jepson, 2003; Lubienski and Lubienski, 2006; Elder and Jepson, 2014). US Catholic schools are, however, all privately funded, which means we cannot untangle the effect of religion from private funding.

Early research comparing students' achievements in private Catholic versus public (state-funded) primary schools supported the widely held view that private schools were beneficial for children's academic performance (e.g. Lee and Stewart, 1989; Jones, 1998). However, children who attend private schools are likely to have more privileged backgrounds and higher average prior cognitive scores compared to children in state-funded education (Ngheim et al, 2015; Sullivan et al, 2014). Therefore, when trying to establish any causal impact of attendance at a private school on cognitive outcomes, it is vitally important to account for selection bias, or pre-existing differences between the two populations of children.

More recent research from both the US (e.g. Carbonaro, 2006; Lubienski, Crane and Lubienski, 2008; Elder and Jepson, 2014) and Australia (Ngheim et al, 2015) has overwhelmingly found that children in state-funded schools either 
outperform those in private schools once background characteristics and prior attainment have been accounted for, or at least that there is no benefit of private school attendance on academic attainment. The lack of a private school premium is particularly notable for mathematics scores. It has been suggested that as maths skills, unlike reading and language skills, are largely learned at school, 'maths' is a particularly good indicator of school effectiveness (Peterson, 1998; Heyneman, 2005).

Turning to evidence based on primary schools from the UK, Gibbons and Silva (2011) used administrative data collected on all children and schools in England to estimate the influence of faith schools on pupil achievement at the end of primary school (age 11), but they did not include private schools. They concluded that although children progressed faster at a faith school 'any advantage was explained by sorting into Faith schools according to preexisting characteristics and preferences'.

As such, to the best of our knowledge, the only existing research to look at the role of fee-paying primary schools on academic outcomes in a UK context was carried out by Ndaji et al (2016) for the Independent School Council. They looked at progress from the start of school up to public examinations at age 16. Focusing on the primary schools analyses, they used Performance Indicators in Primary Schools (PIPS) assessment data (see Tymms et al, 2014), and compared progress made by children in private and State funded primary schools from Reception (age 4-5) to Year 4 (age 7-8) and from Year 4 to Year 6 (age 10-11). They included students' prior ability and a range of school level characteristics 
and found evidence that private school pupils made better progress in both maths and reading from reception to Year 4 , but that the picture was unclear regarding progress from Year 4 to Year 6. However, the (acknowledged) limitation of the research was that they could only include a proxy for an individual student's socio-economic background, which was based on postcode area, and could thus only partly control for the known strong influence social origins have on academic attainment. Socio-economic inequalities in educational attainment develop throughout the life course, and are apparent from early childhood cognitive scores onwards. Social class differences in cognitive attainment are apparent before the start of formal schooling (Duncan and Magnuson 2011), and have been shown to widen during the early years in Britain (Feinstein 2003; Sullivan, Ketende and Joshi 2013). It is therefore vital to take adequate account of the socio-economic position of a child's family when addressing the link between school type and unequal educational trajectories.

In this study, we follow the methodology of Nghiem et al (2015), who used the Longitudinal Study of Australian Children (LSAC) data to compare both cognitive and non-cognitive outcomes for children at state funded, private and faith primary schools. They employed a range of statistical techniques, value-added regression models, propensity score matching techniques and selection on unobservable and observable estimates (see Altonji, 2005; Oster, 2014), and conclude that going to a private or faith (Catholic) primary school has no significant positive impact on children's cognitive or behavioural outcomes. 
family socio economic background together with a wide range of other characteristics. We use data from three of Britain's longitudinal birth cohort studies to examine the association between the unique experience of attending a British private primary school and a child's educational progress, and further, how - and if - this has differed for three generations of children. British private schools are distinctive, partly because Britain absorbed denominational schools into the state sector. Internationally, private schools often cater for religious communities, and are heavily subsidized by church or state. Private schools in Britain, unlike international counterparts, receive no state funding, with the exception of some tax relief, but the cost of attending a private school are increasingly high and the gap in school resources between private and state schools very, very notable. One may hypothesize that the increased fees and resources, and generally more benign environment provided by prep schools in more recent years should have led to better results, and a greater comparative advantage over state schools for the more recent cohorts.

We add to the limited existing evidence base on private primary schooling by answering the following three research questions:

- How do the family backgrounds and individual characteristics of children in the private sector differ from those of children in state funded schools? How has this changed over time?

- Do children in private schools make more academic or cognitive progress during the primary school years? If so, does this relationship stand once family background and individual characteristics have been taken into 
account?

- Is the advantage provided by private primary schools over state schools found in each of three generations of children?

\section{Data sources}

We use data from three British birth cohort studies which have followed up children born in 1958, 1970 and 2000/1. For children in state funded and private primary schools, we compare family background, individual and school characteristics from data broadly 'matched' across the three studies, although there are some differences in question wording or answer categories in some of the individual measures included. (These are detailed in table A1 in the appendix.) We look at performance in a variety of cognitive assessments that the children completed at two different ages near the start and end of primary school. These again varied between studies, but were completed at either age 5 or 7 and later at age 10 or 11.

The analyses were restricted to information that was available across the three cohorts. The descriptive and multivariate analyses are based on the children with complete data in each cohort. We do not make use of data from the oldest birth cohort, the 1946 cohort, as unlike the 1958, 1970 and 2000/1 cohorts it is not open access, and is generally only available to researchers who are collaborating with the NSHD team. For further details on this and all birth cohort studies see Pearson (2016). 
The National Child Development Study (NCDS) follows the lives of 17,000 people born in England, Scotland and Wales in a single week of 1958 (Power and Elliott, 2006). Also known as the 1958 Birth Cohort Study, it collects information on physical and educational development, economic circumstances, employment, family life, health behaviour, wellbeing, social participation and attitudes. Since the birth survey in 1958, there have been nine further 'sweeps' of all cohort members at ages 7, 11, 16, 23, 33, 42, 45, 46, 50 and 55We use information from the first three waves of data collection, from parents, teachers and the cohort members themselves.

1970 cohort: The 1970 British Cohort Study (BCS70)

The 1970 British Cohort Study (BCS70) follows the lives of more than 17,000 people born in England, Scotland and Wales in a single week of 1970 (Elliott and Shepherd, 2006). Over the course of cohort members' lives, the BCS70 has collected information on health, physical, educational and social development, and economic circumstances among other factors. Since the birth survey in 1970, there have been eight waves at ages $5,10,16,26,30,34,38$ and 42 . We use information from the first three waves of data collection, from parents, teachers and the cohort members themselves.

2000/1 cohort: The Millennium Cohort Study (MCS)

The multi-purpose longitudinal Millennium Cohort Study (MCS) is a study of approximately 19,000 babies born to families living in the UK between September 2000 and January 2002, who are followed over time (Plewis 2007). Data has been collected when the children were aged around 9 months, 3 years, 5 
years, 7 years, 11 years and most recently 14 years (Calderwood et al, 2015). We draw on information from the first five sweeps: personal interviews and selfcompletion questionnaires administered to parents, a postal questionnaire of teachers at age 7 , and direct cognitive assessments carried out with the children.

\section{Methodology}

After descriptively profiling the family and individual characteristics of the children in the three cohorts, we run a series of 'value-added' linear regression models and apply propensity score matching (PSM) techniques to see the impact of attending a private primary school on cognitive performance.

We measure academic progress in two ways in our regression modeling. Firstly, we control for the earlier score in exploring associations with the later score: the lagged dependent variable approach (e.g. Sullivan et al., 2013), and secondly construct a 'value-added' score that captures the progress made by a child at the second time point relative to those who had a similar initial score (e.g. Parsons and Platt, 2014, 2017).

The lagged dependent variable approach assumes that different groups have common starting points, and hence is driven by differences at the second time point (Allison 1990). However, such assumptions of a common initial position may be implausible, as we show here children at private schools both start and end their time at primary school with higher average scores (Table 3). The lagged dependent variable approach can therefore lead to the identification of 
differences between groups when the average gap over time has in fact remained constant (Lord's paradox) (see Lord, 1967, 1969; Holland and Rubin, 1983). There is also the issue of 'regression to the mean'. For example, if children at a state school have lower scores at the first time point, then they may be more likely to experience positive change over time.

By also adopting the second 'value-added' approach, we can additionally see whether children at private school make as much or in fact more progress than other children at state schools who started off with equivalent (high) scores. A further advantage of value added scores is that they are not contingent on having precisely the same measure at both time points.

In this analysis we define the peer group for the purposes of calculating value added scores as those in the same 10 per cent of the distribution on the assessment at the earlier time point. For each decile group of scores at time 1, we calculated the average score at time 2 . This average was then subtracted from each individuals actual time 2 score. Hence, a score at or near zero indicates the child made the 'to be expected' progress between the two 'assessments' for their decile group; a positive score indicates more progress was made than was expected; a negative score indicates that less progress was made than expected.

We go on to test the private school advantage further by PSM, a statistical matching technique that attempts to estimate the effect of a treatment, in this instance the treatment is attending a private primary school, by comparing with 
a control group that is very similar to the treated group in terms of the individual and family background covariates that predict receiving the treatment.

Propensity scores for going to a private primary school were calculated from logistic regression models and the fit of the model was assessed using the Hosmer-Lemeshow test (Hosmer and Lemeshow, 2013). The test was not significant in all three cohorts, indicating the fit of the model was good and no important confounders had been omitted from the propensity scores. The 'teffects psmatch' command in Stata 14 (StataCorp, 2015) was used to run the PSM models, and we report the average treatment effect on the treated, those at a private school. A number of sensitivity analyses were carried out. We ran PSM models with individual variables, propensity scores and log of the propensity score. We used the default logit estimator, but also tried other methods such as increasing the number of nearest neighbour matches and caliper approaches (0.01 and 0.001). Results from the different PSM models were consistent. Results for models including the log of the propensity score are reported here, other results available upon request.

To evaluate whether selection bias drives the regression and propensity-score estimates that suggest a positive effect of attending a private primary school on cognitive performance, we apply the approaches developed first by Altonji et al (2005) and later by Oster (2014). The methods seek to obtain an estimate on how strong the selection on unobserved variables would have to be relative to selection on the observed variables to attribute the entire estimated effect of going to a private primary school on cognitive performance to selection bias. 
This is calculated by running the psacalc command in Stata 14 (StataCorp, 2015) after the adjusted linear regressions. Altonji et al (2005) calculations are based on the assumption that there is no measurement error in the data. All variation would be explained if everything that should be included were included in the modeling of a particular outcome, thus $\mathrm{R}^{2}$ would equal 1. Oster (2014) relaxes these assumptions and suggests that even in a perfect world not all variation in an outcome would be explained, setting $\mathrm{R}^{2}$ lower at 0.7 . We apply the assumptions set out by Oster, noting, however, that 0.7 remains a very high explanatory level to expect from a set of results.

For analysis of MCS data, appropriate weights were used to account for the complex sampling design of the survey and non-response bias (Plewis, 2007).

\section{Outcome measures: Cognitive assessments}

Table 1 provides an overview of the cognitive assessments completed by the children in the three cohorts at age 5 or 7 and age 10 or 11 . For further details of the assessments completed by the NCDS cohort see Shepherd (2012), for BCS70 (Parsons, 2015) and for MCS (Connelly, 2013). The assessments completed by cohort members in the different studies and at different ages are not on the same scale, though they are designed to capture the same underlying concept at an age-appropriate level. To measure progress, therefore, all scores were standardized and converted into percentile rank scores. The use of percentile 
rank scores makes it easier to compare performance and progress across different assessments and cohorts. We construct scores from performance in individual assessments sat at Time 1 (age 5 or 7 ) and Time 2 (age 10 or 11). Time 2 is when state educated pupils are in - or nearing - their final year of primary school. For NCDS and BCS70 children, we also derived a composite cognitive score based on performance in all assessments sat at each age. We restricted samples to those who had completed all assessments. In NCDS, over $96 \%$ of cohort members had completed all assessments at each age; in BCS70 this fell slightly but was still very high at over $86 \%$. It is important to acknowledge that children's levels of motivation and compliance will affect their scores in cognitive tests. We do not interpret these tests as tests of innate intelligence, but as tests of capability to complete a particular task under given conditions. Table 2 provides a summary of the scores that are used in the different analyses.

[Table 1 here]

[Table 2 here]

\section{Additional controls}

The following is a list of the additional individual and family background characteristics that were available for all three cohorts and included in the regression and PSM analyses. The measures are known to have an association 
with cognitive and academic performance and/or our key explanatory measure, private primary school attendance.

\section{Individual characteristics}

- Gender: girls tend to have higher scores in assessments of reading and language skills, boys in maths assessments (OECD, 2015).

- Age (MCS only): MCS cohort members are born across a year, whereas the NCDS and BCS70 cohorts are all born within the same week. Older children have a cognitive advantage over younger children (Crawford et al, 2014; Parsons and Hallam, 2014).

- Birth weight: Low birth weight is considered to be an indicator of prenatal disadvantage (Karlson et al, 2010).

- Position in birth order: Parity is a well-established predictor of educational chances, with an advantage for children higher up the birth order (Nisbet, 1953).

- Health (parent assessment): poor childhood health impacts negatively on cognitive and academic performance (e.g. Parsons and Platt, 2014).

- Behaviour problems (parent assessment): this was captured in NCDS and BCS70 by the overall score on the Rutter behaviour scale (Rutter, 1970), and in MCS by the overall Strengths and Difficulties Questionnaire score (Goodman, 1997, 1999). Behaviour problems in childhood are associated with poorer cognitive outcomes (Guttman and Vorhaus, 2012; Brooks, 2014).

- Ethnicity: coded as White British or Black Minority Ethnic (BME) for MCS only. There are differences in cognitive attainment in the early years by 
ethnicity, although much of this is accounted for by poorer family circumstances in BME families (Dearden and Sibieta, 2010; Dearden et al, 2011). The Black Minority Ethnic percentages born in the UK, or later recruited to the study, was very low in NCDS and BCS70.

\section{Family characteristics}

- Family social class: captured from occupation of father (NCDS) or highest occupation of either parent (BCS70 or MCS). Registrar Generals Social Class [RGSC] is measured at the time of the child's birth in NCDS and BCS70. National Statistics Socio-economic classification [NS-SEC] is measured at 9 months in MCS. Social origins have an established relationship with academic performance (Heath et al, 1981; Sullivan et al, 2014).

- Parental Education: whether parents' experienced post-compulsory education: coded as compulsory, one parent extended education, both parents extended education. Parental education levels have a strong relationship with academic achievement of their children (Sullivan et al, 2010).

- Home ownership: Home ownership is an important indicator of wealth (Furley 1989; Tunstall et al, 2013).

- Overcrowding: The ratio of people in the household per room (excluding kitchens and bathrooms). More than one person per room is indicative of living in overcrowded conditions which has a negative impact on educational attainment (Power, 1995; Goux and Maurin, 2003).

- Frequency of reading to the child: in BCS70 parents were asked how many days (0-7) during a week the cohort member had been read to, in MCS 
responses were captured in a 6-category variable from 'never' to 'everyday', and in NCDS in a 3-category variable of 'never' 'occasionally' 'every week'. A positive home learning environment has been found to influence later cognitive performance (e.g. Sammons et al, 2007).

\section{School characteristics}

- Primary school type: classified as State or Private.

\section{Results and Discussion}

\section{Descriptive profile}

Few children, between 2-6\%, attended a private primary school, with this being largest in our analytic sample for children born in 2000/1 and lowest for the cohort born in 1970. Proportions do, however, reflect official data where they are available (see school census data available from 1984 to present day, Independent School Council). Table 3 shows that children at private school consistently came from a privileged socio-economic background. Few of their parents had not experienced some form of extended education and the family was most likely to own their home and to not live in overcrowded living conditions. However, the changing landscape of British society over the fifty years from the mid-1960s to mid-2010s was very apparent among the majority of families with children in state funded schools. This produced an apparent narrowing of the gap in terms of family background characteristics amongst the two groups of children. For example, whereas just 33.7\% of parents of 1958 
cohort members at a state school had experienced some level of extended education, this increased to $45.7 \%$ for parents of the 1970 cohort and to $59.5 \%$ for parents of those born in 2000/1. The comparable figures for parents of children at a private school were $84.2 \%, 92.9 \%$ and $91.4 \%$ respectively. Highest qualification held by parents would have been preferable to include, but was unavailable for the 1958 cohort. In BCS70 and MCS differences between parents by school type remained very apparent. In BCS70, whereas $40.5 \%$ of parents with a child in a state-funded school had no qualifications compared to $5.4 \%$ of parents of children in a private primary school. Conversely, $56.1 \%$ of children in a private primary school had at least one parent with a degree compared to just $13.9 \%$ of children in a state-funded school. In MCS, $82.4 \%$ of children in a private school had a parent who held a degree or higher, compared to $40.3 \%$ of children being state educated.

Similarly, whereas just $41.7 \%$ of parents of 1958 cohort members at a state school owned their home, this increased to $58.1 \%$ for parents of the 1970 cohort and to $60.2 \%$ for parents of those born in $2000 / 1$. The comparable figures for parents of children at a private school were $85.8 \%, 90.6 \%$ and $87.9 \%$ respectively. In terms of personal characteristics, children were split equally by gender in state and private schools. Fewer children at private schools had a low birthweight, more were first born - or higher up the birth order - and they had significantly higher scores in all the cognitive assessments at both age points. More children from black or other minority ethnic groups in the youngest cohort were being educated in private schools. 
[Table 3 here]

\section{Regression analyses}

\section{Private school}

From the descriptives (Table 3) and the unadjusted models in Table 4 we can see that children at a private school in all three cohorts scored significantly higher in each of the cognitive assessments at both time points. The scores for reading and maths assessments in both the 1958 and 1970 cohort were around 20 percentile points higher, and 13 points higher for 'reading' in the youngest MCS cohort.

Although we would expect some of the difference in scores to be associated with prior determinants of private school attendance, the fully adjusted models show that private schooling kept a significant positive effect on the cognitive performance of children as they reached the end of their primary school years even after a child's prior cognitive skills, other personal characteristics and family background had been taken into account. Although the size of the effect was considerably reduced (e.g. from 23.25 percentile points to 8.06 percentile points for reading performance in the 1970 cohort), this effect is evident for each of the three generations of children. In line with some previous findings based on US data (e.g. Heyneman, 2005), maths (and overall cognition) performance at age 11 in NCDS was the only outcome where the positive effect of private schooling became negative - although insignificant - after the inclusion of the full set of controls. (Detailed results are included in Table A1 in the appendix.) 
When re-running the analyses with the value-added progress scores, the above results are replicated. Children at a private primary school make significantly more progress than their peers with similar prior cognitive attainment at a state school. The exceptions, as above, were maths and overall cognition scores in the 1958 cohort. (Detailed results are included in Table A2 in the appendix.)

\section{The effects of other important measures}

As expected, prior cognitive performance had a strong effect on later scores in all three studies even when the range of personal and family characteristics has been taken into account. Other personal characteristics which were significantly associated with increased cognitive progress were being first or higher up the birth order, increased birthweight and having good health, in particular having reported no longstanding limiting illness or condition for children born in 1958 and 1970. Children who were older and members of black or minority ethnic groups had also made more cognitive progress in MCS.

Acknowledging the fact that assessments differed and captured different aspects of cognition (see Table 1), once personal and family background characteristics had been accounted for we found that boys born in 1958 and 2000/1 had higher reading scores than girls at the end of primary school, whereas the opposite was true for those born in 1970. Boys born in 1970 had significantly higher maths and overall cognition progress scores. Among the family characteristics, parental extended education, a professional or managerial occupations and home ownership each had a significant association with children's cognitive 
progress scores. Not living in overcrowded living conditions was positively associated with cognitive progress in the 1958 cohort, but not in the later born cohorts. The more often a child was read to in a week was also associated with cognitive progress for those born in 1970, but not for those born in 1958 or 2000/1- although this may well reflect the different measures and distributions across categories in the different cohorts.

\section{Variation explained}

The set of measures included in the fully adjusted models provided convincing $\mathrm{R}^{2}$ goodness of fit measures. This was particularly so for the 1958 cohort, with an $\mathrm{R}^{2}=.54$ for overall cognition, reflecting that correlations between the earlier and later assessments were strongest for the 1958 cohort. For example, the correlation between the two 'reading' assessments was .62 for the 1958 cohort, .43 for the 1970 cohort and 38 for the youngest cohort. As discussed above, although other characteristics included in the models were significantly associated with the cognitive outcomes, it is the earlier cognitive score that overwhelmingly contributed to the variation explained by the $\mathrm{R}^{2}$ statistic in the fully adjusted models. For example, (not shown) in a model predicting reading performance at age 11 for the 1958 cohort that only included school type and reading performance at age 7 , the $\mathrm{R}^{2}=.36$, only increasing by .07 in the fully adjusted model to .43 (detailed results of all the fully adjusted models are included in Tabl1 A1 in the appendix).

[Table 4 here] 


\section{Propensity Score Matching (PSM)}

In table 5, we show the average treatment effect for the treated (ATET), the children who were being educated at a private school. The models include the $\log$ of the propensity score calculated from all covariates included in the regression modeling. We can see that the reading scores of children at a private school in all three cohorts are significantly higher than their state-educated counterparts, within a range of 3-10 percentage points. For children at a private school in the 1970 cohort, math and overall cognitive performance scores were also higher, 8 percentage points for maths and 10 for overall cognition.

[Table 5 here]

\section{Selection on observables and unobservables}

Using Oster (2014) assumptions, the results in Table 6 suggest that the regression estimate from the fully adjusted models would be solely driven by selection bias if the selection on unobservables were only between $22 \%$ and $40 \%$ as strong as the selection on the observables. Taking BCS70 reading scores as our example, the regression results suggest private school attendance has a positive 8.06 point increase on reading scores for children. However, the estimated bias is 21.11 , implying that the OLS estimate would be solely driven by selection bias if selection on unobservables were only $38 \%$ as strong as selection 
on observables. Put simply, if 'other measures' had been included in the regression models, the positive effect of attending private primary school on cognitive scores would no longer be found $(8.02-21.11=-13.09)$.

We can also obtain the amount the $\mathrm{R}^{2}$ would increase by if the 'missing measures' had been included in the model by multiplying the $\mathrm{R}^{2}$ by the 'implied ratio'. Again using BCS70 reading scores as our example, we can see that the $\mathrm{R}^{2}$ would increase from $\mathrm{R}^{2}=.29$ to $\mathrm{R}^{2}=.40$. Whilst acknowledging that the inclusion of 'other measures' in any model would only help to strengthen the results, when a wide range of other individual and family background covariates - including earlier cognitive performance - have already been included in the model, an increase in the variation explained by the $\mathrm{R}^{2}$ of such a substantial size as .11 would rarely - if ever - be witnessed with the inclusion of a few additional variables.

[Table 6]

\section{Concluding remarks}

The results confirmed that children at private schools from all three generations had a more privileged set of socio-economic circumstances and scored higher in the cognitive assessments at (or near) the start of their time at primary school. Descriptive differences by school type suggested an apparent narrowing of the gap in terms of family background characteristics amongst the two groups of 
children, being most marked for the 1958 cohort and least so for the 2000/1 cohort. However, this is difficult to interpret due to the changing distributions of the socio-economic variables over time. Future work on the more recent cohorts would benefit from including a measure of household income (not available for the older 1958 cohort) which would show the great disparity between children by school type given the ever-increasing and substantial costs associated with attending private school in Britain. Calculations by the author included in this paper show how the cost of sending a child to a private primary school would have been (relatively) far more affordable for an average family in the 1958 cohort than for the $2000 / 1$ cohort, or families today.

Our findings support the view that although cognitive scores at the start of formal schooling are the most important predictors of later cognitive performance (Downey and Condron, 2016), going to a private primary school provides an early advantage for children over their similarly able peers at British state funded primary schools. The advantage remains even when a wide range of family and individual characteristics have been taken into account, and importantly when different analytic techniques were applied. The results were particularly strong for the 1970 and $2000 / 1$ cohorts, supporting the recent work carried out by Ndaji et al (2016), which also showed a greater level of cognitive progress made by children in private primary schools in England. It is important to note here that aggregate value added scores are currently used to evaluate the success or quality of schools in England, since they are not contingent on the performance of the initial intake. Our results using the value-added progress 
scores therefore map onto the measures used for judging progress at the policy level.

Another important finding for some discussion is that in terms of effect size, the benefit of attending a private primary school for academic progress was not commensurate with the associated costs. Parents of the youngest cohort are paying (proportionately) the most, but the benefits were not greater than for the 1970 cohort. Results suggest an eight- to ten-point advantage for the 1970 cohort and a five-point advantage for the 2000/1 cohort. There was however, only a negligible premium of attending private primary school for the older 1958 cohort. The money paid by these families over the primary school years gave no more than a three-point advantage for reading and no advantage at all for maths performance. The fact that increasing school fees have not produced an increased private school advantage is surprising. We can speculate that increased performance pressures on state primary schools may have gone some way to counterbalance the increased resources enjoyed by the private sector. For example, in 2015, the average fees for sending a child to a private primary school was $£ 3,927$ per term (ISC annual report, 2015), thus around $£ 12,000$ per school year. This compares to the annual average spend per pupil in a state funded primary school in England during 2014-15 of £4,308 (Belfield and Sibieta, 2016). A private school therefore has, on average, three times the amount of money to spend on the education of a child than a state funded school in each and every year a child attends school. 
And finally, when concentrating on the findings from the more recent cohorts, our results are in direct contrast to the rigorous studies using data from similar studies based in the USA (Elder and Jepson, 2014) or Australia (Nghiem et al, 2015). This suggests that the private primary school advantage that we have found for the UK does not apply to other national contexts. In other words, the advantage is not inherent to private schooling per se, but is due to the unique nature of the British private school system. In the USA, for example, private schooling is synonymous with religious belief, largely Catholicism. British private schools receive no state funding at all, whereas private schools in Australia do receive some form of state support (Bonnor and Shepherd, 2016), which could help make the fees for attending such schools far more affordable than private schools are for the average British family. As such, British private schools are far more socially exclusive than in other countries, educating proportionally very few school age children. These features, together with the fact that private schools are incredibly well resourced compared to the overwhelming majority of state schools in Britain, go towards explaining the distinctive British prep school advantage that we found. A central aim of preparatory schools is to 'prepare' children for the competitive entrance examinations of the private secondary schools. As such, the children are perhaps schooled in a more academically rigorous and positive manner to meet the expectations of teachers, parents and the children themselves, that they will indeed go on to excel. 


\section{References}

Allison, P.D. (1990). Change scores as dependent variables in regression analysis, Sociological Methodology, 20, 93-114.

Altonji, J., Elder, T. \& Taber, C. (2005). Selection on observed and unobserved variables: assessing the effectiveness of Catholic schools. Journal of Political Economy, 113 (1), 151-184.

Belfield, C. \& Sibieta, L. (2016). Long-run Trends in School Spending in England. IFS Report R115. London: Institute of Fiscal Studies.

Bonner, C. \& Shepherd, B. (2016). Uneven Playing Field: the state of Australia's schools. Centre for Policy Development, Australia. http://cpd.org.au/2016/05/unevenplayingfield/

Brooks, F. (2014). The link between pupil health and wellbeing and attainment A briefing for head teachers, governors and staff in education settings. Public Health England.

https://www.gov.uk/government/uploads/system/uploads/attachment data/fi le/370686/HT briefing layoutvFINALvii.pdf

Calderwood, L., Smith, K., Gilbert, E., Rainsberry, M., Knibbs, S., \& Burston, K. (2015). Securing participation and getting accurate answers from teenage 
children in surveys: lessons from the UK Millennium Cohort Study. Social Research Practice, 1(1), 29-42.

Carbonaro, W. (2006). Public-private differences in achievement among kindergarten students: differences in learning opportunities and student outcomes. American Journal of Education, 113 (1), 31-66.

Connelly, R. (2013). Millennium Cohort Study Data Note: Interpreting Test Scores. CLS Data Note 2013/1. London: Centre for Longitudinal Studies, Institute of Education.

Crawford, C., Dearden, L. \& Greaves, E. (2014). The drivers of month-of-birth differences in children's cognitive and non-cognitive skills. Journal of the Royal Statistical Society (Series A), 177(4), 829-860.

Dearden, L, Ferri, J \& Meghir, C. (2002). The Effect of School Quality on Educational Attainment and Wages. Review of Economics and Statistics, 84, 1-20.

Dearden, L. \& Sibieta, L. (2010). Ethnic inequalities in child outcomes. In Hansen, K, Joshi, H and Dex, S. (Eds), Children of the 21st century (Volume 2): the first five years. Bristol: The Policy Press.

Dearden, L., Sibieta, L. \& Sylva, K. (2011). The socio-economic gradient in early child outcomes: evidence from the Millennium Cohort Study. Longitudinal and Life Course Studies, 2(1), 19-40. 
Delamont, S. (1989). Knowledgeable Women: Structuralism and the Reproduction of Elites. London; New York: Routledge.

DfE (2015). Schools, pupils and their characteristics. SFR 16/2015.

https://www.gov.uk/government/uploads/system/uploads/attachment data/fi le/433680/SFR16 2015 Main Text.pdf

Downey, D. B. \& Condron, D. J. (2016). Fifty Years since the Coleman Report Rethinking the Relationship between Schools and Inequality. Sociology of Education, 89 (3), 208-20.

Duncan, G. J. \& Magnuson, K. (2011). The nature and impact of early achievement skills, attention skills, and behavior problems, Chapter 3 in G. J. Duncan \& Murname, R. J. (Eds). Whither opportunity: Rising Inequality, Schools and Children's Life Chances. New York: Russell Sage Foundation.

Elder, T. \& Jepsen, C. (2014). Are Catholic primary schools more effective than public primary schools? Journal of Urban Economics, 80, 28-38

Elliott, C., Murray, D. \& Pearson, L. (1979). British Ability Scales. Slough: NFER.

Elliott, C. (1996). BAS II Administration and Scoring Manual. London: NfER Nelson Publishing Company Ltd. 
Elliott, C., Smith, P. \& McCulloch, K. (1997). British Ability Scales Second Edition (BAS II). Technical Manual. . London: Nelson.

Elliott, J. \& Shepherd, P. (2006). Cohort Profile: 1970 British birth cohort (BCS70). International Journal of Epidemiology 35(4), 836-43.

Feinstein, L., \& Symons, J. (1999). Attainment in secondary school. Oxford Economic Papers, 51, 300-321

Feinstein, L. (2003). Inequality in the Early Cognitive Development of British Children in the 1970 Cohort. Economica, 70(1), 73-97.

Furley, A. (1989). A bad start in life - children, health and housing, London, Shelter.

Gibbons, S. \& Silva, O. (2011). Faith primary schools: better schools or better pupils? Journal of Labor Economics, 29, 589-635.

Goodman, R. (1997). The Strengths and Difficulties Questionnaire: a research note. Journal of Child Psychology and Psychiatry, 38(5), 581-6

Goodman, R. (1999). The extended version of the Strengths and Difficulties Questionnaire as a guide to child psychiatric caseness and consequent burden. Journal of Child Psychology and Psychiatry, 40(5), 791-9. 
Goux, D. \& Maurin, E. (2003). The effect of overcrowded housing on children's performance at school, Paris, INSEE

(http://pythie.cepremap.ens.fr/ piketty/Papers/GouxMaurin2001.pdf)

Green, F., Machin, S., Murphy, R. \& Zhu, Y. (2012). The changing economic advantage from private schools. Economica 79(316), 658-79.

Green, F., Henseke, G. \& Vignoles, A. (2017). Private schooling and labour market outcomes. British Educational Research Journal, 43, 7-28. doi:10.1002/berj.3256

Gutman, L. \& Vorhaus, J. (2012). The Impact of Pupil Behaviour and Wellbeing on Educational Outcomes. London: DfE.

Heyneman, S. P. (2005). Student Background and Student Achievement: What Is the Right Question? American Journal of Education, 112, 1-9.

Holland, P. W, \& Rubin, D.B. (1983). On Lord's paradox. In H. Wainer \& S. Messick (Eds.), Principals of modern psychological measurement (pp. 3-35). Hillsdale, NJ: Erlbaum.

Hosmer, D. W. \& Lemeshow, S. (2013). Applied Logistic Regression. New York: Wiley. ISBN 978-0-470-58247-3.

Institute of Fiscal Studies. Living Standards, Poverty and Inequality in the UK: 2015. http://www.ifs.org.uk/tools_and_resources/incomes_in_uk 
Independent Schools Council, www.isc.co.uk. ISC annual census 1984 - 2016.

Jepsen, C. (2003). The effectiveness of catholic primary schooling. Journal of Human Resources, 38 (4), 928-941.

Jones, A. M. (1998). Differential effectiveness: catholic and public fourth graders' performance on the 1992 NAEP mathematics assessment. In: Ph.D. Dissertation. Boston College, Boston, MA.

Karlson, K.B., Holm, A. \& Breen, R. (2010). Total, Direct and Indirect Effects in Logit Models. CSER Working Paper 0005. Centre for Strategic Educational Research, Aarhus University.

Lee, V. E. \& Stewart, C. (1989). National Assessment of Educational Progress Proficiency in Mathematics and Science: 1985-1986, Catholic and Public Schools Compared. National Catholic Education Association, Washington (DC).

Lord, E. M. (1967). A paradox in the interpretation of group comparisons. Psychological Bulletin, 68, 304-305.

Lord, F. M. (1969). Statistical adjustments when comparing preexisting groups. Psychological Bulletin, 72, 336-337.

Lubienski, C., Crane, C. \& Lubienski, S. T. (2008). What do we know about school effectiveness? Academic gains in public and private schools. Phi Delta Kappan 89 (9), 689-695. 
Lubienski, S.T. \& Lubienski, C. (2006). School sector and academic achievement: a multilevel analysis of NAEP mathematics data. American Educational Research Journal 43 (4), 651-698.

Macmillan, L., Tyler, C., \& Vignoles, A. (2015). Who gets the top jobs? The Role of Family Background and Networks in Recent Graduates Access to High-Status Professions. Journal of Social Policy, 44, 487-515.

Ndaji, F., Litle, J. \& Coe, R. (2016). A comparison of Academic Achievement in Independent and State Schools. Report for the Independent Schools Council. Centre for Evaluation and Monitoring, Durham University. https://www.isc.co.uk/research/durham-university-academic-value-added$\underline{\text { research-2016/ }}$

Nghiem, H.S., Nguyen, H.T., Khanam, R. \& Connelly, L.B. (2015). Does school type affect cognitive and non-cognitive development in children? Evidence from Australian primary schools. Labour Economics, 33, 55-65.

Nisbet, J. (1953). Family Environment and Intelligence. Eugenics Review XLV, 3142.

OECD, (2015). http://www.oecd.org/els/family/CO3-3-Literacy-scores-bygender-age-10.pdf 
Ogg, T., Zimdars, A. \& Heath, A. (2009). Schooling effects on degree performance: A comparison of the predictive validity of aptitude testing and secondary school grades at Oxford University. British Educational Research Journal, 35, 781-807. doi:10.1080/01411920903165611

Oster, E. (2014). Unobservable selection and coefficient stability: Theory and validation. NBER working paper series Working Paper 19054 http://www.nber.org/papers/w19054

Pearson, H. (2016). The Life Project: The extraordinary story of our ordinary lives. London: Penguin Random House.

Peterson, P. E. (1998). School Choice: A Report Card, in Peterson P. E. \& Hassel, B. C. (eds.), Learning from School Choice. Washington, D.C: Brookings Institution Press.

Plewis, I. (Ed). (2007). Millennium Cohort Study First Survey: Technical Report on Sampling (4th Edition). London: Centre for Longitudinal Studies, Institute of Education.

Power, S., Whitty, G., Youdell, D. (1995). No place to learn - homelessness and education. London, Shelter.

Power, C. \& Elliott, J. (2006). Cohort Profile: 1958 British birth cohort (National Child Development Study). International Journal of Epidemiology, 35 (1), 34-41. 
Rutter, M., Tizard, J. \& Whitmore, K. (1970). Education, Health and Behaviour. London: Longmans.

Sammons, P., Sylva, K., Melhuish, E., Siraj-Blatchford, I., Taggart, B. \& Grabbe, Y. (2007). Effective pre-school and primary education 3-11 project (EPPE 3-11): influences on children's attainment and progress in Key Stage 2: cognitive outcomes in Year 5. London: Institute of Education, University of London.

Shepherd, P. (2012). 1958 National Child Development Study User Guide: Measures of ability at ages 7 to 16. http://www.cls.ioe.ac.uk/page.aspx?\&sitesectionid=780\&sitesectiontitle=User + guides+to+dataset

StataCorp. (2015). Stata Statistical Software: Release 14. College Station, TX: StataCorp LP.

Sullivan, A., \& Heath, A. (2003). Intakes and Examination Results at State and Private Schools. Pp. 77-104 in British Private Schools: research on policy and practice, edited by G. Walford. London: Woburn Press.

Sullivan, A., Joshi, H. \& Leonard, D. (2010). Single-sex Schooling and Academic Attainment at School and through the Lifecourse. American Education Research Journal, 47 (1), 6-36. 
Sullivan, A., Ketende, S. \& Joshi. H. (2013). Social Class and Inequalities in Early Cognitive Scores. Sociology 47 (6), 1187-206.

The Sutton Trust (2008). Primed for Success? London: The Sutton Trust.

The Sutton Trust (2016). Research Brief: Oxbridge Admissions. London: The Sutton Trust.

Tunstall, R., Bevan, M., Bradshaw, J., Croucher, K., Duffy, S., Hunter, C., Jones, A., Rugg, J., Wallace, A. \& Wilcox, S. (2013). The links between housing and poverty: an evidence review. London: Joseph Rowntree Foundation.

Tymms, P., Merrell, C., Hawker, D. \& Nicholson, F. (2014). Performance Indicators in Primary Schools: A comparison of performance on entry to school and the progress made in the first year in England and four other jurisdictions. Research Report to the DfE.

Wilkins, S. (2016). John Catt's Preparatory Schools 2016, 19 th Edition. Woodbridge: John Catt's Educational Ltd. 
Tables

Table 1: Overview of Cognitive assessments

\begin{tabular}{|c|c|c|c|}
\hline & NCDS & BCS70 & MCS \\
\hline Time 1 & $\begin{array}{l}\text { Age } 7 \\
\text { Southgate Group Reading Test: } \\
\text { Word recognition and comprehension. } \\
\text { Particularly suited to identifying backward } \\
\text { readers. } \\
\text { Problem Arithmetic Test: Arithmetic } \\
\text { Copying Designs Test: An assessment of } \\
\text { visual-motor co-ordination } \\
\text { Human Figure Drawing Test (Draw-a-Man): } \\
\text { Intended to reflect conceptual maturity }\end{array}$ & $\begin{array}{l}\text { Age } 5 \\
\text { Copying Designs Test: An assessment of } \\
\text { visual-motor co-ordination } \\
\text { English Picture Vocabulary Test: A test of } \\
\text { verbal vocabulary } \\
\text { Human Figure Drawing (Draw-a-Man) } \\
\text { Test: Intended to reflect conceptual maturity } \\
\text { Complete a Profile Test: complete an } \\
\text { outline picture of a human face in profile by } \\
\text { filling in features } \\
\text { Schonell Reading Test: a reading test } \\
\text { designed to assess a child's 'reading age' }\end{array}$ & $\begin{array}{l}\text { Age } \mathbf{5} \\
\text { BAS II }{ }^{2} \text { Naming Vocabulary: Expressive } \\
\text { Verbal Ability } \\
\text { BAS II Pattern Construction: Spatial } \\
\text { Problem Solving } \\
\text { BAS II Picture Similarities: Non Verbal } \\
\text { Reasoning }\end{array}$ \\
\hline Time 2 & $\begin{array}{l}\text { Age 11 } \\
\text { Reading Comprehension Test: } \\
\text { Reading comprehension } \\
\text { Arithmetic/ Mathematics Test } \\
\text { General Ability Test: Mental ability } \\
\text { Copying Designs Test: } \\
\text { An assessment of visual-motor co-ordination }\end{array}$ & $\begin{array}{l}\text { Age 10 } \\
\text { Shortened Edinburgh Reading Test: A test } \\
\text { of word recognition } \\
\text { Friendly Maths Test: A multiple choice test } \\
\text { Pictorial Language Comprehension Test: } \\
\text { Based on the English picture vocabulary test. } \\
\text { Spelling Dictation task: Dictation task, both } \\
\text { real and made-up words. } \\
\text { British Ability Scales }{ }^{1} \text { (BAS): verbal } \\
\text { subscales (Word Definitions and Word } \\
\text { Similarities) and non-verbal subscales } \\
\text { (Recall of Digits and Matrices). }\end{array}$ & $\begin{array}{l}\text { Age 11 } \\
\text { BAS II Verbal Similarities: measure of } \\
\text { 'crystallised intelligence' }\end{array}$ \\
\hline
\end{tabular}

${ }^{1}$ British Ability Scales (Elliott et al, 1979). ${ }^{2}$ British Ability Scales II (Elliott, 1996). Full details of the BAS II sub-tests, their design and their theoretical basis are provided in the BAS II Technical Manual (Elliott et al,1997). 
Table 2: summary of assessments

\begin{tabular}{|c|c|c|c|c|c|}
\hline \multirow{2}{*}{ NCDS } & \multicolumn{2}{c|}{ BCS70 } & \multicolumn{2}{c|}{ MCS } \\
Time 1 & Time 2 & Time 1 & Time 2 & Time 1 & Time 2 \\
\hline Reading & Reading & EPVT & Reading & Naming & $\begin{array}{c}\text { Verbal } \\
\text { Vocabulary }\end{array}$ \\
\hline Similarities
\end{tabular}


Table 3: characteristics by children in state or private primary schools

\begin{tabular}{|c|c|c|c|c|c|c|c|}
\hline & \multicolumn{2}{|c|}{1958 cohort } & \multicolumn{2}{|c|}{1970 cohort } & \multicolumn{2}{|c|}{$2000 / 1$ cohort } \\
\hline & & State & Private & State & Private & State & Private \\
\hline \multicolumn{2}{|c|}{$\%$ private primary school } & & 3.3 & & 2.2 & & 5.5 \\
\hline \multicolumn{8}{|c|}{ Outcome measures } \\
\hline \multicolumn{8}{|c|}{ Mean percentile rank scores } \\
\hline \multicolumn{2}{|c|}{ 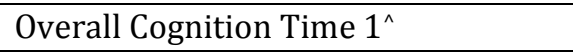 } & 52.8 & $69.7^{*}$ & 50.5 & $68.1^{*}$ & & \\
\hline \multicolumn{2}{|c|}{ Reading score Time 1} & 55.2 & $69.1^{*}$ & 53.0 & $66.7^{*}$ & 53.7 & $63.2^{*}$ \\
\hline \multicolumn{2}{|c|}{ Maths score Time 1} & 50.6 & $66.3^{*}$ & & & & \\
\hline \multicolumn{2}{|c|}{ Overall Cognition Time 2} & 51.7 & $72.8^{*}$ & 52.6 & $80.3^{*}$ & & \\
\hline \multicolumn{2}{|c|}{ Reading score Time 2} & 51.1 & $72.9^{*}$ & 52.4 & $75.7^{*}$ & 50.8 & $63.8^{*}$ \\
\hline \multicolumn{2}{|c|}{ Maths score Time 2} & 50.6 & $70.2^{*}$ & 52.4 & $76.0^{*}$ & & \\
\hline \multicolumn{8}{|c|}{ Individual characteristics } \\
\hline \multicolumn{2}{|c|}{ Gender: \% Male } & 51.3 & 52.1 & 51.5 & 50.0 & 50.7 & 49.3 \\
\hline \multicolumn{2}{|c|}{ Mean birthweight (kgs) } & 3.35 & $3.43^{*}$ & 3.33 & $3.41^{*}$ & 3.35 & 3.40 \\
\hline \multicolumn{2}{|c|}{ Mean birth order } & 2.3 & $2.1^{*}$ & 2.1 & $1.9^{*}$ & 1.9 & $1.7^{*}$ \\
\hline \multicolumn{2}{|c|}{ Health: \% limiting illness } & 8.0 & 6.1 & 3.5 & $6.5^{*}$ & 7.0 & $4.4^{*}$ \\
\hline \multicolumn{2}{|c|}{ Ethnicity: \% BME } & & & 3.5 & 1.7 & 11.1 & $15.4^{*}$ \\
\hline \multicolumn{2}{|c|}{ Mean age at test (11) } & & & & & 11.2 & 11.1 \\
\hline \multicolumn{2}{|c|}{$\begin{array}{l}\text { Behaviour scores } \\
\text { (mean percentile rank) }\end{array}$} & & & & & & \\
\hline Rutter 7 / Ru & r 5 / SDQ 5 & 48.2 & 43.0 & 47.9 & 45.0 & 47.1 & $36.3^{*}$ \\
\hline \multicolumn{8}{|c|}{ Family characteristics } \\
\hline \multicolumn{8}{|l|}{ Parent edu } \\
\hline \multicolumn{2}{|c|}{$\% 0$ parent extended edu } & 66.4 & $15.8^{*}$ & 54.3 & $7.1^{*}$ & 40.5 & $8.6^{*}$ \\
\hline \multicolumn{2}{|c|}{$\% 1$ parent extended edu } & 23.7 & $23.9^{*}$ & 25.9 & $24.7^{*}$ & 35.6 & $30.6^{*}$ \\
\hline \multicolumn{2}{|c|}{$\% 2$ parents extended edu } & 10.0 & $60.3^{*}$ & 19.8 & $68.2^{*}$ & 23.9 & $60.8^{*}$ \\
\hline \multicolumn{2}{|l|}{ Home owners } & 41.7 & $85.8^{*}$ & 58.1 & $90.6^{*}$ & 60.2 & $87.9^{*}$ \\
\hline $\begin{array}{l}\% \text { Non-overc } \\
(<1 \text { person } \mathrm{pe}\end{array}$ & $\begin{array}{l}\text { wded home } \\
\text { room) }\end{array}$ & 32.3 & $75.5^{*}$ & 61.7 & $90.0^{*}$ & 74.4 & $91.4^{*}$ \\
\hline Social class: $R$ & $C / N S S E C^{2}$ & & & & & & \\
\hline$\% \mathrm{~V}$ or IV / se & i-routine and routine & 21.9 & $3.6^{*}$ & 15.6 & $2.4^{*}$ & 49.0 & $11.5^{*}$ \\
\hline$\%$ IIIm/lo sup & echnical & 62.0 & $30.3^{*}$ & 32.4 & $11.2^{*}$ & 10.1 & $3.5^{*}$ \\
\hline \% IIInm/sma & mp-intermediate & 12.1 & $40.0^{*}$ & 31.6 & $17.1^{*}$ & 21.5 & $31.1^{*}$ \\
\hline \% II or I/man & erial-professional & 4.0 & $26.1^{*}$ & 20.4 & $69.4^{*}$ & 19.4 & $53.8^{*}$ \\
\hline Reading to ch & & & & & & & \\
\hline $\begin{array}{l}\text { \% Hardly } \\
\text { ever } 3\end{array}$ & Never/less often ${ }^{4}$ & 11.1 & $9.4^{*}$ & 10.8 & $2.4^{*}$ & 5.1 & $1.0^{*}$ \\
\hline $\begin{array}{l}\% \\
\text { Occasionally }\end{array}$ & 1- 2 days & 33.0 & $25.5^{*}$ & 18.4 & $7.7^{*}$ & 14.8 & $7.3^{*}$ \\
\hline$\%$ & 3-6 days & & & 31.3 & $28.2^{*}$ & 29.3 & $26.3^{*}$ \\
\hline $\begin{array}{l}\text { \% Every } \\
\text { week }\end{array}$ & Every day & 55.9 & $65.2^{*}$ & 39.5 & $61.8^{*}$ & 50.8 & $65.4^{*}$ \\
\hline & $N(100 \%)$ & 9728 & 330 & 7495 & 170 & 10113 & 569 \\
\hline
\end{tabular}

Note: $\quad{ }^{1}$ refer to Table 2 for details of specific assessments at Time 1 and Time 2.

${ }^{2}$ RGSC=NCDS and BCS70, NSSEC, MCS; ${ }^{3}$ NCDS ${ }^{4}$ BCS70 and MCS;

${ }^{*}$ Indicates differences by school type are statistically significant at $5 \%$ level.

Descriptive statistics are run on the complete case 'reading' samples. 
Table 4: effects of private school on cognitive outcomes - regression results

\begin{tabular}{|c|c|c|c|c|c|c|c|}
\hline & \multicolumn{2}{|c|}{ NCDS } & \multicolumn{2}{|c|}{ BCS70 } & \multicolumn{2}{|c|}{ MCS $^{1}$} \\
\hline & & unadj & adj & unadj & adj & unadj & adj \\
\hline \multicolumn{8}{|c|}{ Reading performance } \\
\hline \multirow[t]{4}{*}{ Private school } & & $21.80^{* * *}$ & $2.99^{*}$ & $23.25^{* * *}$ & $8.06^{* * *}$ & $12.29^{* * *}$ & $4.57^{* *}$ \\
\hline & & $(1.58)$ & $(1.28)$ & $(2.28)$ & (1.99) & $(1.10)$ & (1.01) \\
\hline & $\mathrm{R}^{2}$ & 0.02 & 0.43 & 0.01 & 0.29 & 0.02 & 0.21 \\
\hline & $N$ & 10058 & 10058 & 7665 & 7665 & 10682 & 10682 \\
\hline \multicolumn{8}{|c|}{ Maths performance } \\
\hline \multirow[t]{4}{*}{ Private school } & & $19.62^{* * *}$ & -1.84 & $23.58^{* * *}$ & $8.54^{* * *}$ & & \\
\hline & & $(1.69)$ & $(1.41)$ & $(2.25)$ & $(1.96)$ & & \\
\hline & $\mathrm{R}^{2}$ & 0.01 & 0.39 & 0.02 & 0.29 & & \\
\hline & $N$ & 10020 & 10020 & 7113 & 7113 & & \\
\hline \multicolumn{8}{|c|}{ Overall performance } \\
\hline \multirow[t]{4}{*}{ Private school } & & $21.07^{* * *}$ & 0.14 & $27.72^{* * *}$ & $9.89^{* * *}$ & & \\
\hline & & $(1.67)$ & $(0.21)$ & $(2.28)$ & $(1.85)$ & & \\
\hline & $\mathrm{R}^{2}$ & 0.01 & 0.54 & 0.02 & 0.39 & & \\
\hline & $N$ & 9737 & 9737 & 6875 & 6875 & & \\
\hline
\end{tabular}

Regression coefficients, standard errors in parentheses. $p<0.05,{ }^{* *} p<0.01,{ }^{* * *} p<0.001$

${ }^{1}$ MCS descriptive statistics produced using 'svy' command to weight the data. Regression, PSM and psacalc results produced with design and attrition weights included in the modeling. This explains the slight discrepancy between the size of the private school advantage produced by descriptive (13.0) and unadjusted regression (12.29) analyses. 
Table 5: effects of private school on cognitive outcomes - PSM results

\begin{tabular}{|c|c|c|c|c|}
\hline \multicolumn{2}{|l|}{ Reading } & NCDS & BCS70 & MCS \\
\hline $\begin{array}{l}\text { Reading } \\
\text { ATET }\end{array}$ & & $\begin{array}{l}\mathbf{3 . 0 4}^{\wedge} \\
(1.23)\end{array}$ & $\begin{array}{l}\mathbf{9 . 4 1}^{* * *} \\
(2.56)\end{array}$ & $\begin{array}{c}\mathbf{5 . 1 6}^{\text {*** }} \\
(1.42)\end{array}$ \\
\hline & $N$ & 10058 & 7665 & 10682 \\
\hline $\begin{array}{l}\text { Maths } \\
\text { ATET }\end{array}$ & & $\begin{array}{l}\mathbf{- 1 . 3 0} \\
(1.54)\end{array}$ & $\begin{array}{l}\mathbf{8 . 4 2}^{* *} \\
(2.76)\end{array}$ & \\
\hline & $N$ & 10020 & 7113 & \\
\hline $\begin{array}{l}\text { Overall } \\
\text { ATET }\end{array}$ & & $\begin{array}{c}\mathbf{0 . 6 2} \\
(1.91)\end{array}$ & $\begin{array}{c}\mathbf{1 0 . 0 3}^{\text {*** }} \\
(2.39)\end{array}$ & \\
\hline & $N$ & 9737 & 6875 & \\
\hline
\end{tabular}


Table 6: estimation of bias in regression estimates of the effect of private primary schooling on cognitive outcomes

\begin{tabular}{l|c|cc|} 
& $\begin{array}{c}\text { OLS estimate } \\
(\mathrm{a})\end{array}$ & $\begin{array}{c}\text { Oster (rmax = 0.7) } \\
\text { Estimated bias } \\
(\mathrm{b})\end{array}$ & $\begin{array}{c}\text { Implied ratio / delta } \\
(\mathrm{c})\end{array}$ \\
\hline $\begin{array}{l}\text { Reading } \\
\text { NCDS }\end{array}$ & $2.99^{*}$ & 13.59 & 0.22 \\
$\mathrm{R}^{2}\left(\mathrm{R}^{2}\right.$ increase $)$ & .43 & & $.52(.09)$ \\
\hline $\mathrm{BCS70}$ & $8.06^{* * *}$ & 21.11 & 0.38 \\
$\mathrm{R}^{2}\left(\mathrm{R}^{2}\right.$ increase $)$ & .29 & & $.40(.11)$ \\
\hline $\mathrm{MCS}$ & $4.57^{* * *}$ & 19.04 & 0.24 \\
$\mathrm{R}^{2}\left(\mathrm{R}^{2}\right.$ increase $)$ & .21 & & $.26(.05)$ \\
\hline Maths & $8.54^{* * *}$ & 21.30 & 0.40 \\
$\mathrm{BCS70}$ & .29 & & $.41(.12)$ \\
$\mathrm{R}^{2}\left(\mathrm{R}^{2}\right.$ increase $)$ & .29 & & \\
\hline
\end{tabular}

Note: The estimates in column (a) are the same as the adjusted OLS estimates in Table 4. The estimates in column (b) are the estimates of bias in the estimates in (a) based on the condition that selection on observables equals selection on unobservables.

The estimates in column (c) are the OLS estimates in (a) divided by the estimated bias (b). This represents the ratio of selection on unobservables to selection on observables that would be consistent with no effect of private school on cognitive outcomes. 


\section{Appendix}

Table A1: fully adjusted 'value-added' progress regression results

\begin{tabular}{|c|c|c|c|c|c|c|c|c|}
\hline & \multicolumn{3}{|c|}{ Reading } & \multicolumn{2}{|c|}{ Maths } & \multicolumn{2}{|c|}{ Overall cognition } \\
\hline & & 1958 & 1970 & $2000 / 1$ & 1958 & 1970 & 1958 & 1970 \\
\hline \multirow{2}{*}{\multicolumn{2}{|c|}{$\%$ private primary school }} & 2.30 & $7.66^{* * *}$ & $4.17^{* *}$ & -2.41 & $7.96^{* * *}$ & -0.21 & $9.24^{* * *}$ \\
\hline & & $(1.27)$ & $(2.00)$ & $(1.29)$ & $(1.42)$ & $(1.97)$ & $(1.22)$ & $(1.87)$ \\
\hline \multicolumn{9}{|c|}{ Individual characteristics } \\
\hline \multicolumn{2}{|c|}{ Gender: ref-cat male } & $-4.75^{* * *}$ & $5.75^{* * *}$ & $-3.32^{* * *}$ & 0.39 & $-4.15^{* * *}$ & -0.05 & $-1.83^{* * *}$ \\
\hline \multicolumn{2}{|c|}{ 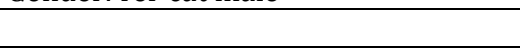 } & $(0.43)$ & $(0.58)$ & $(0.50)$ & $(0.48)$ & $(0.59)$ & $(0.41)$ & $(0.55)$ \\
\hline \multirow{2}{*}{\multicolumn{2}{|c|}{ Birthweight (kgs) }} & $1.41^{* * *}$ & $2.13^{* * *}$ & 0.86 & $2.68^{* * *}$ & $1.76^{* *}$ & $1.22^{* *}$ & $1.75^{* *}$ \\
\hline & & $(0.41)$ & $(0.56)$ & $(0.45)$ & $(0.45)$ & $(0.56)$ & $(0.39)$ & $(0.53)$ \\
\hline \multirow{2}{*}{\multicolumn{2}{|c|}{ Birth order }} & $-0.65^{* * *}$ & $-1.43^{* * *}$ & $-0.73^{*}$ & $-2.27^{* * *}$ & $-0.91^{* * *}$ & $-1.48^{* * *}$ & $-1.38^{* * *}$ \\
\hline & & $(0.15)$ & $(0.26)$ & $(0.30)$ & $(0.17)$ & $(0.27)$ & $(0.14)$ & $(0.25)$ \\
\hline \multirow{2}{*}{\multicolumn{2}{|c|}{ Limiting illness }} & -0.73 & $-7.11^{* * *}$ & 0.69 & $-2.91^{* *}$ & $-7.66^{* * *}$ & -1.20 & $-5.59^{* * *}$ \\
\hline & & $(0.80)$ & $(0.85)$ & $(1.16)$ & $(0.89)$ & $(0.86)$ & $(0.76)$ & $(0.82)$ \\
\hline \multirow{2}{*}{\multicolumn{2}{|c|}{ Ethnicity BME: ref-cat White }} & & & $7.52^{* * *}$ & & & & \\
\hline & & & & (1.19) & & & & \\
\hline \multirow{2}{*}{\multicolumn{2}{|c|}{ Age at test (Time 2) }} & & & $2.89^{* *}$ & & & & \\
\hline & & & & $(0.89)$ & & & & \\
\hline \multirow{2}{*}{\multicolumn{2}{|c|}{ Percentile rank behaviour score }} & -0.01 & $-0.04^{* * *}$ & $-0.08^{* * *}$ & $-0.08^{* * *}$ & $-0.04^{* * *}$ & $-0.03^{* * *}$ & $-0.04^{* * *}$ \\
\hline & & $(0.01)$ & $(0.01)$ & $(0.01)$ & $(0.01)$ & $(0.01)$ & $(0.01)$ & $(0.01)$ \\
\hline \multicolumn{9}{|c|}{ Family characteristics } \\
\hline \multicolumn{9}{|c|}{$\begin{array}{l}\text { Parent education: ref-cat no extended } \\
\text { education }\end{array}$} \\
\hline \multirow{2}{*}{\multicolumn{2}{|c|}{1 parent extended edu }} & $4.67^{* * *}$ & $5.41^{* * *}$ & $1.90^{* *}$ & $6.17^{* * *}$ & $4.31^{* * *}$ & $5.15^{* * *}$ & $4.54^{* * *}$ \\
\hline & & $(0.54)$ & $(0.73)$ & $(0.73)$ & $(0.60)$ & $(0.73)$ & $(0.51)$ & $(0.69)$ \\
\hline \multirow{2}{*}{\multicolumn{2}{|c|}{2 parents extended edu }} & $8.58^{* * *}$ & $9.34^{* * *}$ & $3.40^{* * *}$ & $12.20^{* * *}$ & $8.58^{* * *}$ & $8.51^{* * *}$ & $8.98^{* * *}$ \\
\hline & & $(0.82)$ & $(0.88)$ & $(0.81)$ & $(0.91)$ & $(0.89)$ & $(0.78)$ & $(0.84)$ \\
\hline \multirow{2}{*}{\multicolumn{2}{|c|}{ Home ownership }} & $3.00^{* * *}$ & $3.84^{* * * *}$ & $3.00^{* * *}$ & $3.65^{* * *}$ & $3.52^{* * *}$ & $2.21^{* * *}$ & $3.46^{* * *}$ \\
\hline & & $(0.49)$ & $(0.66)$ & $(0.77)$ & $(0.55)$ & $(0.67)$ & $(0.46)$ & $(0.63)$ \\
\hline \multirow{2}{*}{\multicolumn{2}{|c|}{$\begin{array}{l}\text { Overcrowding: ref-cat more than } 1 \\
\text { person per room }\end{array}$}} & $3.12^{* * *}$ & 0.02 & 1.21 & $1.89^{* * *}$ & $-1.42^{*}$ & $1.90^{* * *}$ & -0.57 \\
\hline & & $(0.50)$ & $(0.69)$ & $(0.82)$ & $(0.56)$ & $(0.69)$ & $(0.47)$ & $(0.66)$ \\
\hline \multicolumn{9}{|c|}{$\begin{array}{l}\text { Social class: ref-cat V or IV / semi- } \\
\text { routine and routine }\end{array}$} \\
\hline \multirow{2}{*}{\multicolumn{2}{|c|}{$\%$ IIIm/lo sup-technical }} & $2.33^{* * *}$ & -0.13 & 1.29 & $3.30^{* * *}$ & -0.21 & $2.09^{* * *}$ & 0.15 \\
\hline & & $(0.55)$ & $(0.90)$ & $(0.88)$ & $(0.61)$ & $(0.92)$ & $(0.52)$ & $(0.88)$ \\
\hline$\%$ IIInm/sma & ermediate & $5.18^{* * *}$ & $4.02^{* * * *}$ & $2.53^{* * *}$ & $8.84^{* * *}$ & $3.55^{* * *}$ & $5.55^{* * *}$ & $4.59^{* * *}$ \\
\hline & & $(0.85)$ & $(0.96)$ & $(0.70)$ & $(0.94)$ & $(0.97)$ & $(0.80)$ & $(0.92)$ \\
\hline$\%$ II or I/man & rofessional & $5.94^{* * *}$ & $5.92^{* * *}$ & $4.11^{* * *}$ & $8.55^{* * *}$ & $4.90^{* * *}$ & $6.03^{* * *}$ & $6.41^{* * *}$ \\
\hline & & $(1.22)$ & $(1.10)$ & $(0.82)$ & $(1.35)$ & $(1.11)$ & $(1.15)$ & $(1.06)$ \\
\hline $\begin{array}{l}\text { Reading to } \mathrm{ch} \\
\text { ever/Never } / \mathrm{L}\end{array}$ & Hardly & & & & & & & \\
\hline Occasionally & 1- 2 days & 0.15 & 1.65 & -0.86 & -1.37 & -0.56 & -0.42 & 1.17 \\
\hline & & $(0.75)$ & (1.12) & $(1.30)$ & $(0.83)$ & $(1.14)$ & $(0.71)$ & $(1.09)$ \\
\hline & 3-6 days & & $3.30^{* *}$ & -0.67 & & $2.60^{*}$ & & $4.07^{* * *}$ \\
\hline & & & $(1.04)$ & (1.32) & & $(1.06)$ & & $(1.01)$ \\
\hline Every week & Every day & $2.43^{* * *}$ & $4.71^{* * *}$ & 0.15 & -0.43 & $3.55^{* * *}$ & 0.81 & $5.97^{* * *}$ \\
\hline & & $(0.72)$ & $(1.04)$ & $(1.27)$ & $(0.80)$ & $(1.06)$ & $(0.68)$ & $(1.01)$ \\
\hline & _cons & -3.26 & -3.26 & $-33.59^{* *}$ & $-7.20^{* * *}$ & -3.08 & $-4.99^{* *}$ & $-8.86^{* * *}$ \\
\hline & & $(1.86)$ & $(1.86)$ & $(10.64)$ & $(2.07)$ & $(2.54)$ & $(1.76)$ & $(2.41)$ \\
\hline & $\mathrm{R}^{2}$ & 0.09 & 0.12 & 0.07 & 0.13 & 0.09 & 0.09 & 0.12 \\
\hline & $N(100 \%)$ & 10058 & 7665 & 10682 & 10020 & 7113 & 9737 & 6875 \\
\hline
\end{tabular}


Table A2: fully adjusted lagged dependent variable regression results

\begin{tabular}{|c|c|c|c|c|c|c|c|}
\hline & \multicolumn{3}{|c|}{ Reading } & \multicolumn{2}{|c|}{ Maths } & \multicolumn{2}{|c|}{ Overall cognition } \\
\hline & 1958 & 1970 & $2000 / 1$ & 1958 & 1970 & 1958 & 1970 \\
\hline \multirow[t]{2}{*}{$\%$ private primary school } & $2.99^{*}$ & $8.06^{* * * *}$ & $4.35^{* * *}$ & -1.84 & $8.54^{* * *}$ & 0.14 & $9.89^{* * *}$ \\
\hline & $(1.28)$ & $(1.99)$ & $(1.27)$ & $(1.41)$ & $(1.96)$ & $(1.21)$ & $(1.85)$ \\
\hline \multicolumn{8}{|l|}{ Percentile rank cognitive scores } \\
\hline Reading score Time 1 & $0.54^{* * *}$ & $0.32^{* * *}$ & $0.30^{* * *}$ & & & & \\
\hline & $(0.01)$ & $(0.01)$ & $(0.01)$ & & & & \\
\hline Maths score Time 1 & & & & $0.47^{* * *}$ & & & \\
\hline & & & & $(0.01)$ & & & \\
\hline Overall Cognition Time 1 & & & & & $0.34^{* * *}$ & $0.64^{* * *}$ & $0.41^{* * *}$ \\
\hline & & & & & $(0.01)$ & $(0.01)$ & $(0.01)$ \\
\hline Individual characteristics & & & & & & & \\
\hline \multirow[t]{2}{*}{ Gender: ref-cat male } & $-3.95^{* * *}$ & $4.99^{* * *}$ & $-3.25^{* * *}$ & 0.14 & $-3.87^{* * *}$ & 0.20 & $-1.49^{* *}$ \\
\hline & $(0.44)$ & $(0.58)$ & $(0.50)$ & $(0.48)$ & $(0.58)$ & $(0.41)$ & $(0.55)$ \\
\hline \multirow[t]{2}{*}{ Birthweight (kgs) } & $1.82^{* * *}$ & $2.61^{* * *}$ & $0.99^{*}$ & $3.19^{* * *}$ & $2.39^{* * * *}$ & $1.76^{* * *}$ & $2.47^{* * * *}$ \\
\hline & $(0.41)$ & $(0.55)$ & $(0.44)$ & $(0.45)$ & $(0.56)$ & $(0.38)$ & $(0.53)$ \\
\hline \multirow[t]{2}{*}{ Birth order } & $-0.91^{* * *}$ & $-1.59^{* * *}$ & $-0.99^{* *}$ & $-2.33^{* * *}$ & $-1.04^{* * *}$ & $-1.66^{* * *}$ & $-1.52^{* * *}$ \\
\hline & $(0.15)$ & $(0.26)$ & $(0.30)$ & $(0.17)$ & $(0.26)$ & $(0.14)$ & $(0.25)$ \\
\hline \multirow[t]{2}{*}{ Limiting illness } & -1.17 & $-7.53^{* * *}$ & 1.12 & $-3.77^{* * *}$ & $-8.18^{* * *}$ & $-2.24^{* *}$ & $-6.13^{* * *}$ \\
\hline & $(0.80)$ & $(0.84)$ & $(1.16)$ & $(0.88)$ & $(0.85)$ & $(0.75)$ & $(0.81)$ \\
\hline Ethnicity BME: ref-cat White & & & $6.29^{* * *}$ & & & & \\
\hline & & & $(1.19)$ & & & & \\
\hline Age at test (Time 2) & & & $3.44^{* * *}$ & & & & \\
\hline & & & $(0.91)$ & & & & \\
\hline \multirow{2}{*}{ Percentile rank behaviour score } & $-0.02^{* *}$ & $-0.06^{* * *}$ & $-0.09^{* * *}$ & $-0.09^{* * *}$ & $-0.05^{* * *}$ & $-0.04^{* * *}$ & $-0.06^{* * *}$ \\
\hline & $(0.01)$ & $(0.01)$ & $(0.01)$ & $(0.01)$ & $(0.01)$ & $(0.01)$ & $(0.01)$ \\
\hline \multicolumn{8}{|l|}{ Family characteristics } \\
\hline \multicolumn{8}{|l|}{$\begin{array}{l}\text { Parent education: ref-cat no extended } \\
\text { education }\end{array}$} \\
\hline 1 parent extended edu & $5.49^{* * *}$ & $5.85^{* * * *}$ & $2.11^{* *}$ & $6.93^{* * *}$ & $4.93^{* * *}$ & $5.81^{* * *}$ & $5.24^{* * *}$ \\
\hline & $(0.55)$ & $(0.72)$ & $(0.73)$ & $(0.60)$ & $(0.73)$ & $(0.51)$ & $(0.69)$ \\
\hline 2 parents extended edu & $10.44^{* * *}$ & $10.15^{* * *}$ & $3.83^{* * *}$ & $13.31^{* * *}$ & $9.58^{* * *}$ & $9.61^{* * *}$ & $10.12^{* * *}$ \\
\hline & $(0.83)$ & $(0.88)$ & $(0.81)$ & $(0.91)$ & $(0.89)$ & $(0.77)$ & $(0.84)$ \\
\hline Home ownership & $3.35^{* * *}$ & $4.49^{* * * *}$ & $3.36^{* * *}$ & $4.01^{* * * *}$ & $4.30^{* * * *}$ & $2.62^{* * *}$ & $4.41^{* * *}$ \\
\hline & $(0.49)$ & $(0.66)$ & $(0.76)$ & $(0.54)$ & $(0.66)$ & $(0.46)$ & $(0.63)$ \\
\hline $\begin{array}{l}\text { Overcrowding: ref-cat more than } 1 \\
\text { person per room }\end{array}$ & $3.37^{* * * *}$ & 0.45 & 1.22 & $2.14^{* * *}$ & -0.82 & $2.13^{* * *}$ & 0.13 \\
\hline & $(0.50)$ & $(0.68)$ & $(0.82)$ & $(0.55)$ & $(0.69)$ & $(0.47)$ & $(0.65)$ \\
\hline $\begin{array}{l}\text { Social class: ref-cat V or IV / semi- } \\
\text { routine and routine }\end{array}$ & & & & & & & \\
\hline$\%$ IIIm/lo sup-technical & $2.56^{* * *}$ & 0.34 & $1.50^{\wedge}$ & $3.71^{* * *}$ & 0.32 & $2.56^{* * *}$ & 0.75 \\
\hline & $(0.55)$ & $(0.90)$ & $(0.89)$ & $(0.61)$ & $(0.92)$ & $(0.51)$ & $(0.87)$ \\
\hline$\%$ IIInm/small emp-intermediate & $5.74^{* * * *}$ & $4.65^{* * *}$ & $2.78^{* * *}$ & $9.30^{* * *}$ & $4.13^{* * *}$ & $6.13^{* * *}$ & $5.25^{* * *}$ \\
\hline & $(0.85)$ & $(0.95)$ & $(0.69)$ & $(0.93)$ & $(0.97)$ & $(0.79)$ & $(0.91)$ \\
\hline$\%$ II or I/managerial-professional & $7.12^{* * * *}$ & $6.91^{* * *}$ & $4.68^{* * *}$ & $8.91^{* * *}$ & $5.77^{* * * *}$ & $6.66^{* * *}$ & $7.42^{* * *}$ \\
\hline & $(1.22)$ & $(1.10)$ & $(0.82)$ & $(1.34)$ & $(1.11)$ & $(1.14)$ & $(1.05)$ \\
\hline $\begin{array}{l}\text { Reading to child: ref-cat 'Hardly } \\
\text { ever/Never /Less often' }\end{array}$ & & & & & & & \\
\hline Occasionally & -0.81 & $2.28^{*}$ & -0.75 & -1.37 & 0.15 & -0.48 & 1.94 \\
\hline & $(0.75)$ & $(1.11)$ & $(1.31)$ & $(0.83)$ & $(1.14)$ & $(0.70)$ & $(1.07)$ \\
\hline $3-6$ days & & $4.47^{* * * *}$ & -.48 & & $3.61^{* * *}$ & & $5.16^{* * *}$ \\
\hline & & $(1.03)$ & $(1.31)$ & & $(1.06)$ & & $(1.00)$ \\
\hline Every week & 1.18 & $6.47^{* *+*}$ & 0.44 & -0.54 & $4.72^{* * * *}$ & 0.74 & $7.24^{* * *}$ \\
\hline & $(0.72)$ & $(1.04)$ & $(1.27)$ & $(0.79)$ & $(1.06)$ & $(0.67)$ & $(1.00)$ \\
\hline _cons & $16.41^{* * *}$ & $12.48^{* * *}$ & -3.79 & $17.37^{* * *}$ & $27.70^{* * *}$ & $10.72^{* * *}$ & $17.91^{* * *}$ \\
\hline & $(1.89)$ & $(2.51)$ & (10.79) & $(2.08)$ & $(2.54)$ & $(1.75)$ & $(2.40)$ \\
\hline $\mathrm{R}^{2}$ & 0.43 & 0.29 & 0.21 & 0.39 & 0.29 & 0.54 & 0.39 \\
\hline$N(100 \%)$ & 10058 & 7665 & 10682 & 10020 & 7113 & 9737 & 6875 \\
\hline
\end{tabular}

